\title{
Storage Time of Cryopreserved Embryos and Pregnancy Outcomes: A Dose-Response Meta-Analysis
}

\section{Lagerdauer kryokonservierter Embryos und Schwangerschafts- ausgang: eine Metaanalyse der Dosis-Wirkungs-Beziehung}

(c) (1) $\ominus$

\author{
Authors \\ Affiliations \\ 1 Sun Yat-sen University First Affiliated Hospital, \\ Guangzhou, China \\ 2 Sun Yat-sen University Zhongshan School of Medicine, \\ Guangzhou, China \\ 3 Zhengzhou University First Affiliated Hospital, Zhengzhou, \\ China
}

Yuanlin Ma ${ }^{1}$, Xiaochen Liu ${ }^{2}$, Gaohui Shi ${ }^{1}$, Yongxiang Liu ${ }^{1}$, Shurui Zhou ${ }^{2}$, Wenhui Hou ${ }^{3}$, Yanwen Xu ${ }^{1}$

Key words

storage time, cryopreservation, embryo transfer,

meta-analysis

Schlüsselwörter

Lagerdauer, Kryokonservierung, Embryotransfer, Metaanalyse

$\begin{array}{ll}\text { received } & 24.8 .2020 \\ \text { accepted after revision } & 29.11 .2020\end{array}$

Bibliography

Geburtsh Frauenheilk 2021; 81: 311-320

DOI 10.1055/a-1326-1830

ISSN 0016-5751

(c) 2021. The Author(s).

This is an open access article published by Thieme under the terms of the Creative Commons Attribution-NonDerivative-NonCommercial-License, permitting copying and reproduction so long as the original work is given appropriate credit. Contents may not be used for commercial purposes, or adapted, remixed, transformed or built upon. (https://creativecommons.org/licenses/by-nc-nd/4.0/)

Georg Thieme Verlag KG, Rüdigerstraße 14,

70469 Stuttgart, Germany

Correspondence

Yanwen Xu

Sun Yat-sen University First Affiliated Hospital

ZhongshanEr Road No. 1, Yuexiu District, 510080 Guangzhou, Guangdong, China

xuyanwen663000@126.com

Supplementary material is available under

https://doi.org/10.1055/a-1326-1830

\section{ABSTRACT}

Purpose Cryopreservation techniques have become an essential part of assisted reproduction technology. Embryos may be cryopreserved for several years before transfer, and the safety of long-term cryopreservation needs to be considered. This dose-response meta-analysis was conducted to evaluate whether there were dose-response relationships between the storage time of cryopreserved embryos and pregnancy outcomes such as survival rate, implantation rate, miscarriage rate, clinical pregnancy rate, and congenital malformation rate.

Methods After searching the databases PubMed, Embase, MEDLINE, CCRT and related reviews up until June 4, 2020, seven studies were included for analysis. Two reviewers extracted the relevant information and independently assessed the study quality using the Newcastle-Ottawa scale. Potential linear or non-linear dose-response relationships were assessed with a random-effect dose-response meta-analysis.

Results No dose-response association was found between duration of embryo cryostorage and survival rate, implantation rate, miscarriage rate, clinical pregnancy rate or congenital malformation rate.

Conclusion The interval between the start of embryo cryopreservation and frozen/thawed embryo transfer does not influence pregnancy outcomes.

\section{ZUSAMMENFASSUNG}

Zielsetzung Kryokonservierungstechniken sind inzwischen zu einem wesentlichen Bestandteil der assistierten Reproduktionstechnologie geworden. Embryos können mehrere Jahre lang kryokonserviert werden, bevor sie transferiert werden. Das bedeutet, dass man sich auch wegen der Sicherheit der langfristigen Kryokonservierung Gedanken machen muss. Diese Metaanalyse wurde durchgeführt, um herauszufinden, ob es eine Dosis-Wirkungs-Beziehung zwischen der Lagerdauer von kryokonservierten Embryos und dem Schwangerschaftsausgang gibt, z. B. ob die Kryokonservierung sich auf die Überlebensrate, Implantationsrate, Fehlgeburtsrate, klinische Schwangerschaftsrate und angeborene Fehlbildungsrate auswirkt. 
Methoden Es wurde eine Datenbanksuche von PubMed, Embase, MEDLINE und CCRT bis zum 4. Juni 2020 durchgeführt, und verschiedene Überblicksdarstellungen wurden zusätzlich überprüft. Insgesamt wurden 7 Studien in die Analyse aufgenommen. Die Daten wurden von 2 Wissenschaftlern extrahiert, die die Daten unabhängig voneinander unter Zuhilfenahme der Newcastle-Ottawa-Skala auswerteten. Potenzielle lineare bzw. nicht lineare Dosis-Wirkungs-Beziehungen wurden mithilfe einer Zufallseffekt-Metaanalyse überprüft.
Ergebnisse Es gab keine Dosis-Wirkungs-Beziehung zwischen der Lagerdauer kryokonservierter Embryos und der Überlebensrate, Implantationsrate, Fehlgeburtsrate, klinischen Schwangerschaftsrate oder angeborenen Fehlbildungsrate.

Schlussfolgerung Die Zeitspanne zwischen der Kryokonservierung von Embryos und dem Transfer von eingefrorenen/ aufgetauten Embryonen hat keine Auswirkung auf den Schwangerschaftsausgang.

\section{Introduction}

Since the first successful pregnancy following transfer of a cryopreserved embryo was reported in 1983 [1], cryopreservation techniques have become an essential part of assisted reproduction technology (ART). According to statistics from the European Society for Reproductive Medicine and Embryology (ESHRE), the number of frozen/thawed embryo transfer (FET) cycles carried out in Europe were 129693 cycles in 2011, and the percentage of FET cycles out of the total number of cycles rose from $28 \%$ in 2010 to $32 \%$ in 2011. In many countries such as Switzerland, Finland, Netherland, Sweden, and Iceland, the percentages of FET cycles exceed $50 \%$ [2].

Embryos are cryopreserved for many medical or social reasons, including to preserve supernumerary embryos, decrease the risk of ovarian hyperstimulation syndrome (OHSS), preserve the fertility of women who need ovarian resection, radiotherapy or chemotherapy, and for embryo donation programs. Cryopreservation has resulted in a global reduction in the number of multiple pregnancies as it reduces the number of embryos transferred in a single transfer. Societal pressures have also played a significant role in delaying childbearing, with cryopreservation now an available choice.

In recent years, with the sustainable increase in the number of IVF/ICSI cycles, the improvements in ovulation induction and laboratory techniques, as well as the emphasis on fertility preservation, the number of frozen embryos has increased, and many of them have been frozen for several years. Although embryos kept in long-term cryostorage can result in live births, the safety of long-term cryopreservation needs to be considered, as many manipulations could change cryostorage conditions such as liquid nitrogen levels or tank temperatures, thus damaging the viability of the embryos. In a mouse model, it was found that survival rate, fertilization rate and embryonic development of mouse oocytes were significantly affected by cryopreservation storage times [3]. However, several cohort studies [4-10] showed that long-term storage ( $<8$ years) of embryos had no negative effect on pregnancy outcomes. Live births after transferring embryos cryopreserved for more than 10 years were reported [11,12]. Overall, how long frozen embryos can remain in storage and whether the storage time influences pregnancy outcomes remains controversial, and the dose-response relationship between the duration of time embryos remain in cryostorage and pregnancy outcomes has not been investigated.
A dose-response meta-analysis offers a potential solution to the aforementioned questions. It enables both linear and non-linear dose-response relationships to be evaluated by pooling multiple studies to create greater statistical power $[11,12]$. Therefore, we carried out a dose-response meta-analysis to examine the relationship between duration of storage time and pregnancy outcomes.

\section{Material and Methods}

\section{Inclusion and exclusion criteria}

To be included for analysis, a study had to meet all of the following criteria:

1. It was a cohort study;

2. The population was human;

3. The study must look at the duration of storage time of cryopreserved embryos;

4. The embryo was not donated;

5. Investigated subjects were blastocysts or cleavage stage embryos.

Case-series, case-control studies, and abstracts were ruled out. Studies that presented insufficient data with regard to our prespecified outcome parameters were also excluded.

\section{Search strategy and study selection}

Electronic searches of PubMed, Embase, MEDLINE and the Cochrane Controlled Trials Register (CCTR) were carried out, covering the period from the start of the respective database up until June 4,2020 . Subjects had to be human, but there was no restriction with regard to region, publication type, or language (see Supplemental Table S1 for the detailed search strategy). Reference lists of identified articles were also searched. The titles and abstracts of selected articles were independently analyzed by two of the authors to evaluate whether they complied with the inclusion criteria. If necessary, the full text of an article was carefully scanned. Any disagreements between reviewers were resolved by consensus. Studies that evaluated the association between storage time and pregnancy outcomes were included for metaanalysis. 


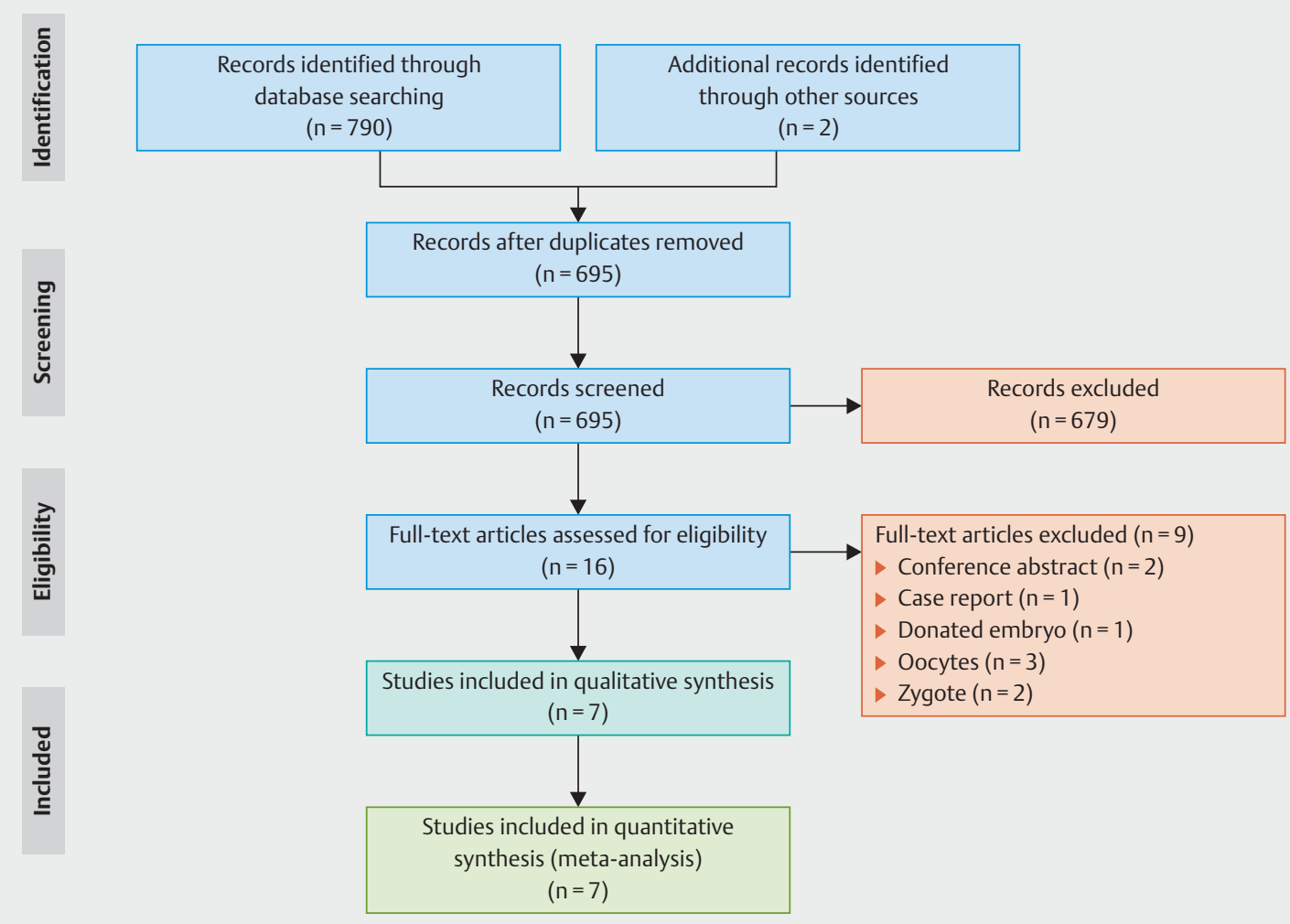

- Fig. 1 Study selection process for the meta-analysis.

\section{Data extraction and quality assessment}

Two reviewers independently extracted data from the full-text copies of all of the included studies, using a standardized form. Information obtained from the studies, including author, publication year, country where the study was conducted, study design, number of patients, duration of follow-up, developmental stage of embryo, cryopreservation technique, methods of fertilization, number of cases, details of storage time, etc., were analyzed. The same reviewers independently evaluated the quality of the studies using the Newcastle-Ottawa scale (NOS) [15]. Disagreements between reviewers were resolved by consensus.

\section{Data synthesis and analysis}

All statistical analyses were conducted using Review Manager (version 5.3, Cochrane Collaboration, Oxford, UK) and STATA (version 14.0, STATA Corp, College Station, TX, USA). The meta-analysis was performed in accordance with the Preferred Reporting Items for Systematic Reviews and Meta-analysis (PRISMA) guidelines [16]. Endpoints of the analysis were pregnancy outcomes, including survival rate, implantation rate, clinical pregnancy rate, miscarriage rate, live birth rate and congenital malformation rate.

Dichotomous outcome data from individual trials were analyzed using odds ratio (OR) or risk difference (RD). The $95 \%$ confidence intervals $(\mathrm{Cl})$ were also computed for individual trials [17]. A random-effects model was utilized. We used "month" as the unit of storage time since it was reported by most of the included studies. When a study only reported the range of storage times, we used the average values of the lower and upper limits of the category. When the highest category was open ended, its value was calculated as 1.2 times the lower limit. When the lowest category was open ended, its value was calculated as the average of the upper limit and 0 .

We considered the lowest category of storage time as the reference category and calculated the OR or RD and the respective $95 \% \mathrm{Cl}$ using a random-effects model weighted with the MantelHaenszel method [18]. We also examined cryopreservation technique-specific effects by conducting separate meta-analyses for both vitrification and the slow-freezing rapid-thawing method. We only carried out a dose-response meta-analysis when it had statistical significance. For a dose-response meta-analysis, we first explored linear trends between storage time and outcome using the method described by Greenland and Longnecker $[13,19]$. Next, we estimated potential non-linear trends using restricted cubic splines with three knots in the dose-response regression model $[13,14]$.

Heterogeneity was analyzed by $\mathrm{I}^{2}$ test. A value for $\mathrm{I}^{2}$ of $0 \%$ indicated no observed heterogeneity, and higher values showed increased heterogeneity. $\mathrm{P}<0.05$ was considered statistically significant. A sensitivity analysis was done to test which study was the reason for the heterogeneity. 


\section{Results}

\section{Trial flow and study characteristics}

After searching databases and reference lists, we initially identi-

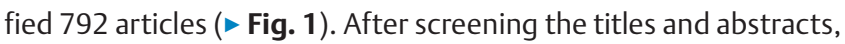
16 potentially eligible articles were retrieved for full-text screening. However, a further 9 articles were excluded ( 2 conference abstracts, 1 case report, 1 study which investigated donated embryos, and 5 other studies which looked at oocytes or zygotes). Therefore, only 7 articles were included in this analysis. Details on the articles included in our analysis are summarized in $>$ Table 1. Supplemental Table S2 shows the calculated OR or RD for different storage times. All included studies have been published as full manuscripts, and most have been evaluated as moderatequality studies, except one which was considered a high-quality study (see Supplemental Table S2).

One article [4] included all cycles with a single embryo transfer. Only two studies [4,7] reported maternal age at the time of oocyte retrieval. One study [5] did not describe the methods of fertilization used, and the other two studies [4,7] only focused on blastocysts. For the analyses relating to specific cryopreservation techniques, four studies reported using vitrification and three studies reported using slow-freezing. All results are shown in - Fig. 2.

\section{Meta-analysis}

Survival rate

Four studies assessed the survival rate. The pooled OR of the survival rate for the highest versus the lowest category of storage time was 0.74 (95\% Cl $[0.44,1.23])$ ( Fig. 2 a) with significant heterogeneity between studies $\left(I^{2}=76 \%, p=0.006\right)$, suggesting no association between storage time and survival rate. The results of the cryopreservation technique-specific analysis showed a pooled OR for vitrification and slow-freezing of $0.67(95 \% \mathrm{Cl}$ $[0.33,1.37])$ and $0.92(95 \% \mathrm{Cl}[0.72,1.18])$, respectively, which indicated no association between storage time and survival rate for either vitrification or slow-freezing.

\section{Implantation rate}

The implantation rate was reported in five studies. Pooling the results showed no significant differences in implantation rates (OR $1.05,95 \% \mathrm{Cl}[0.78,1.42])$ ( $\vee$ Fig. 2 b) and no significant heterogeneity $\left(I^{2}=36 \%, P=0.18\right)$. Cryopreservation technique-specific analysis showed a pooled OR of $0.84(95 \% \mathrm{Cl}[0.57,1.24])$ and $1.24(95 \% \mathrm{Cl}[0.90,1.72])$ for vitrification and slow-freezing, re-

- Table 1 Summary of studies included in the dose-response meta-analysis of storage time and pregnancy outcomes.

\begin{tabular}{|c|c|c|c|c|c|c|c|c|c|c|c|}
\hline $\begin{array}{l}\text { Study } \\
\text { (year) }\end{array}$ & $\begin{array}{l}\text { Re- } \\
\text { gion }\end{array}$ & Design & $\begin{array}{l}\text { Number of } \\
\text { patients| } \\
\text { thaw } \\
\text { cycles }\end{array}$ & Duration & $\begin{array}{l}\text { Develop- } \\
\text { mental } \\
\text { stage of } \\
\text { embryo }\end{array}$ & $\begin{array}{l}\text { Cryopres- } \\
\text { ervation } \\
\text { technique }\end{array}$ & $\begin{array}{l}\text { Methods } \\
\text { of fertil- } \\
\text { ization }\end{array}$ & $\begin{array}{l}\text { Pregnan- } \\
\text { cy out- } \\
\text { comes }\end{array}$ & Storage time frame & $\begin{array}{l}\text { Average } \\
\text { storage } \\
\text { time }\end{array}$ & $\begin{array}{l}\text { NOS } \\
\text { scores }\end{array}$ \\
\hline $\begin{array}{l}\text { Ueno } \\
2018\end{array}$ & Japan & $\begin{array}{l}\text { retro- } \\
\text { spective }\end{array}$ & $7409 / 8736$ & $\begin{array}{l}\text { Jan } 2007 \\
\text { to Dec } \\
2015\end{array}$ & blastocyst & $\begin{array}{l}\text { vitrifica- } \\
\text { tion }\end{array}$ & IVF & $\begin{array}{l}\text { SR, CPR, } \\
M R, L B R \\
\text { CMR }\end{array}$ & $\begin{array}{l}0-2 \text { months; } 2-13 \text { months; } \\
13-97 \text { months }\end{array}$ & NA & 7 \\
\hline Li 2017 & China & $\begin{array}{l}\text { retro- } \\
\text { spective }\end{array}$ & $735 / 786$ & $\begin{array}{l}\text { Jan } 2013 \\
\text { to Oct } \\
2013\end{array}$ & $\begin{array}{l}\text { cleavage- } \\
\text { stage } \\
\text { embryos }\end{array}$ & $\begin{array}{l}\text { vitrifica- } \\
\text { tion }\end{array}$ & NA & $\begin{array}{l}\text { SR, IR, } \\
\text { CPR, MR, } \\
\text { LBR, CMR }\end{array}$ & $\begin{array}{l}1-3 \text { months; } 4-6 \text { months; } \\
\text { 7-12 months; } 13-24 \\
\text { months; } 25-60 \text { months }\end{array}$ & NA & 5 \\
\hline $\begin{array}{l}\text { Liu } \\
2014\end{array}$ & China & $\begin{array}{l}\text { retro- } \\
\text { spective }\end{array}$ & $\mathrm{NA} / 867$ & $\begin{array}{l}\text { Jan } 2005 \\
\text { to March } \\
2012\end{array}$ & $\begin{array}{l}\text { cleavage- } \\
\text { stage } \\
\text { embryos }\end{array}$ & $\begin{array}{l}\text { slow } \\
\text { freezing }\end{array}$ & IVF & $\begin{array}{l}\text { SR, IR, } \\
\text { CPR, MR, } \\
\text { LBR }\end{array}$ & $\begin{array}{l}12-23 \text { months; } 24-35 \\
\text { months; } 36-47 \text { months; } \\
\text { > } 48 \text { months }\end{array}$ & NA & 5 \\
\hline $\begin{array}{l}\text { Wirleit- } \\
\text { ner } \\
2013\end{array}$ & Austria & $\begin{array}{l}\text { retro- } \\
\text { spective }\end{array}$ & NA/603 & $\begin{array}{l}\text { Jan } 2009 \\
\text { to Apr } \\
2012\end{array}$ & blastocysts & $\begin{array}{l}\text { vitrifica- } \\
\text { tion }\end{array}$ & $\begin{array}{l}\text { IVF, ISCI } \\
\text { IMSI }\end{array}$ & $\begin{array}{l}\text { SR, IR, } \\
\text { CPR, MR, } \\
\text { LBR, CMR }\end{array}$ & $\begin{array}{l}0-3 \text { months; } 3-6 \text { months; } \\
6-12 \text { months; } 12-24 \\
\text { months; } 24-36 \text { months; } \\
\text { 36-48 months; } 47-72 \\
\text { months }\end{array}$ & 446 days & 6 \\
\hline $\begin{array}{l}\text { Aflatoo- } \\
\text { nian } \\
2013\end{array}$ & Iran & $\begin{array}{l}\text { retro- } \\
\text { spective }\end{array}$ & $651 / 651$ & $\begin{array}{l}\text { Jan } 2009 \\
\text { to Jan } \\
2012\end{array}$ & $\begin{array}{l}\text { cleavage- } \\
\text { stage } \\
\text { embryos }\end{array}$ & $\begin{array}{l}\text { vitrifica- } \\
\text { tion }\end{array}$ & IVF, ISCI & IR, CPR & $\begin{array}{l}<90 \text { days; } 90-365 \text { days; } \\
\text { 365-730 days; } 730-1095 \\
\text { days; }>1095 \text { days }\end{array}$ & $\begin{array}{l}296.72 \pm \\
301.82 \text { days }\end{array}$ & 5 \\
\hline $\begin{array}{l}\text { Ashrafi } \\
2011\end{array}$ & Iran & $\begin{array}{l}\text { retro- } \\
\text { spective }\end{array}$ & $222 / 247$ & $\begin{array}{l}\text { March } \\
2006 \text { to } \\
\text { March } \\
2008\end{array}$ & $\begin{array}{l}\text { cleavage- } \\
\text { stage } \\
\text { embryos }\end{array}$ & $\begin{array}{l}\text { slow } \\
\text { freezing }\end{array}$ & IVF, ISCI & IR, CPR & $\leq 180$ days $;>180$ days & $\begin{array}{l}170 \\
(53-1671) \\
\text { days }\end{array}$ & 5 \\
\hline $\begin{array}{l}\text { Riggs } \\
2010\end{array}$ & USA & $\begin{array}{l}\text { retro- } \\
\text { spective }\end{array}$ & $\mathrm{NA} / 537$ & $\begin{array}{l}\text { Nov } 1986 \\
\text { to Feb } \\
2007\end{array}$ & $\begin{array}{l}\text { cleavage- } \\
\text { stage } \\
\text { embryos }\end{array}$ & $\begin{array}{l}\text { slow } \\
\text { freezing }\end{array}$ & IVF & LBR & $\begin{array}{l}30-100 \text { days; } 101-365 \\
\text { days; } 366-730 \text { days; } 731- \\
1095 \text { days; }>1095 \text { days }\end{array}$ & $\begin{array}{l}346 \pm 492 \\
\text { days }\end{array}$ & 5 \\
\hline
\end{tabular}

$I V F=$ in vitro fertilization, ICSI = intracytoplasmic sperm injection, IMSI = intracytoplasmic morphologically selected injection, $S R=$ survival rate, $I R=$ implantation rate, $\mathrm{CPR}=$ clinical pregnancy rate, $\mathrm{MR}=$ miscarriage rate, $\mathrm{LBR}=$ live birth rate, $\mathrm{CMR}=$ congenital malformation rate 
spectively. There was no association between storage time and implantation rate.

\section{Clinical pregnancy rate}

Six studies reported the clinical pregnancy rate. No significant difference in the clinical pregnancy rate was found (OR 0.94, 95\% Cl $[0.83,1.07])(\triangleright$ Fig. 2 c) and there was no significant heterogeneity between studies $\left(I^{2}=1 \%, p=0.41\right)$. Cryopreservation technique-specific analysis showed a pooled OR of $0.91(95 \% \mathrm{Cl}$ $[0.80,1.03])$ for vitrification and $1.22(95 \% \mathrm{Cl}[0.85,1.75])$ for slow-freezing, respectively. No association was found between storage time and clinical pregnancy rate.

\section{Miscarriage rate}

The miscarriage rate was calculated for four studies. The pooled results revealed no significant differences in miscarriage rates for the highest compared to the lowest category of storage time (OR $1.05,95 \% \mathrm{Cl}[0.85,1.29])$ ( $\bullet$ Fig. 2 d) and no significant heterogeneity $\left(I^{2}=0.0 \%, P=0.46\right)$. After carrying out cryopreservation technique-specific analysis, we got a pooled OR of $1.20(95 \% \mathrm{Cl}$ $[0.74,1.96])$ for vitrification and $1.11(95 \% \mathrm{Cl}[0.38,3.26])$ for slow-freezing, respectively, showing no association between storage time and miscarriage rate.

\section{Live birth rate}

We performed a meta-analysis of the live birth rates of five trials. The pooled OR of the live birth rate of the highest compared to the lowest category of storage time was $0.99(95 \% \mathrm{Cl}[0.78$, 1.25]) ( $\triangleright$ Fig. 2e) with no significant heterogeneity $\left(I^{2}=29 \%\right.$, $p=0.23$ ). After carrying out cryopreservation technique-specific analysis, the pooled $\mathrm{OR}$ was $0.90(95 \% \mathrm{Cl}[0.79,1.03])$ for vitrification and 1.37 (95\% Cl $[0.76,2.46])$ for slow-freezing, respectively. The results showed no association between storage time and live birth rate.

\section{Congenital malformation rate}

Congenital malformation rates were reported in three studies using vitrification. No significant differences were found (RD -0.00 , $95 \% \mathrm{Cl}[-0.02,0.01])(\triangleright$ Fig. $2 \mathbf{f})$ and there was no significant heterogeneity between studies $\left(I^{2}=0 \%, p=0.70\right)$. The results showed no association between storage time and congenital malformation rate.

\section{Dose-response analysis}

The results of the highest versus the lowest category of storage time showed no significant differences for all pregnancy outcomes. It suggests that there is no linear or non-linear association between the duration of embryo cryostorage and pregnancy outcomes.

\section{Sensitivity analysis and publication bias}

Six of the seven cohorts were of moderate quality, and one was considered high quality according to the criteria of the NOS. All were therefore included in the sensitivity analysis which showed no significant changes in any of the outcomes, except for the survival rate. After eliminating one study, the survival rate was found to be significantly lower for the highest category of storage time following vitrification [10].

We did not construct funnel plots for publication bias or perform meta-regression analyses because of the limited number of studies included in this meta-analysis.

\section{Discussion}

Embryos which have been cryopreserved for several years may still result in live births after transfer. However, there is an issue with the safety of long-term storage. To the best of our knowledge, this is the first dose-response meta-analysis investigating an association between the duration of cryostorage and pregnancy outcomes. We found that a long storage time (less than 8 years) did not influence pregnancy outcomes of FET cycles.

Our group has previously reported on live births achieved with a cohort of human embryos which were cryopreserved for more than 12 years [11]. Another study showed that human embryos cryopreserved for 18 years maintained their pluripotency similar to fresh embryos and were not adversely affected by the long duration of cryopreservation [20].

During long-term storage, the viability of embryos may be influenced, mainly by temperature fluctuations and radiation. Pogozhykh et al. [21] investigated the impact of temperature fluctuations on frozen stored placental multipotent stromal cells to simulate repeated temperature fluctuations in biobanking or interruptions to the cold chain due to transportation and stocking events. They found that the quantity, viability, and metabolic parameters of these cells were influenced by both the number of cycles with temperature fluctuations and the fluctuation range. The increasing number of apoptotic changes was only related to the number of cycles of temperature fluctuations. However, the differentiation potential of these cells was not significantly compromised. Gamma radiation is a common research tool used to explore the impact of cryostorage times. There was no detrimental effect on the morphological appearance, development into morulae and blastocysts, implantation rate, or live birth rates when mouse embryos were exposed up to 200 cGy radiation, which is equal to 2000 years of background radiation [22]. However, problems related to development, i.e., increased DNA damage, decreased body length, increased mortality rates, and increased number of morphological deformities, were observed in zebrafish embryo exposed to 1 Gy gamma radiation [23].

Most individual studies included in this study showed no association between storage time and pregnancy outcomes, which is in accordance with our results. Only one study showed a significant decrease in survival rates with increasing duration of cryostorage. However, using multivariable logistic regression analysis, Ueno et al. found that only the time from insemination to vitrification correlated with survival rates but not the duration of cryostorage [4]. In contrast, a recently published study, which investigated the effect of the storage time of embryos on pregnancy outcomes in 24698 patients following the first embryo transfer cycles, found the rates of implantation, clinical pregnancy, multiple pregnancy, and live births decreased with prolonged storage time, although no significant difference in survival rates was found between the different groups [24]. Although the sample 


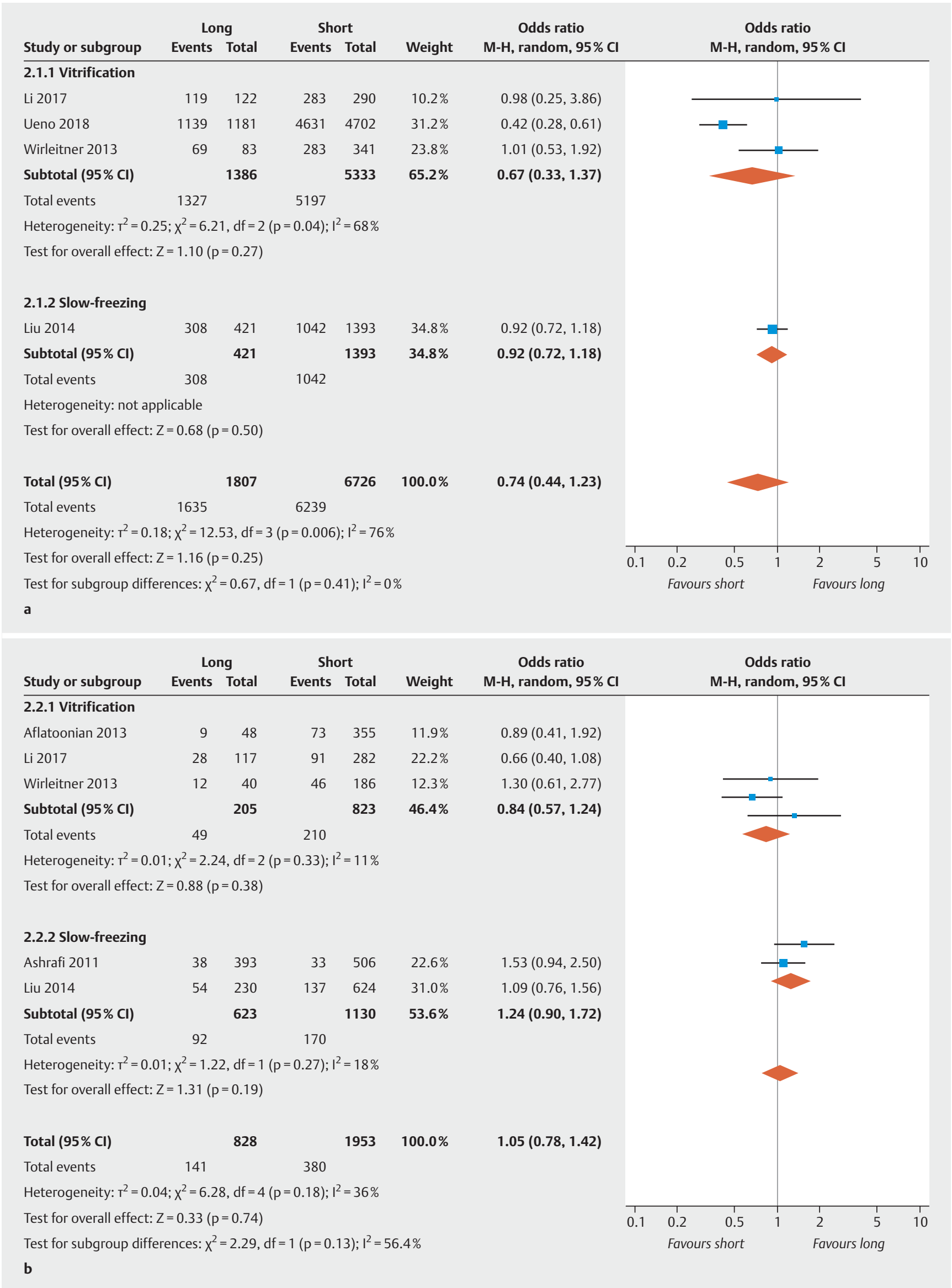




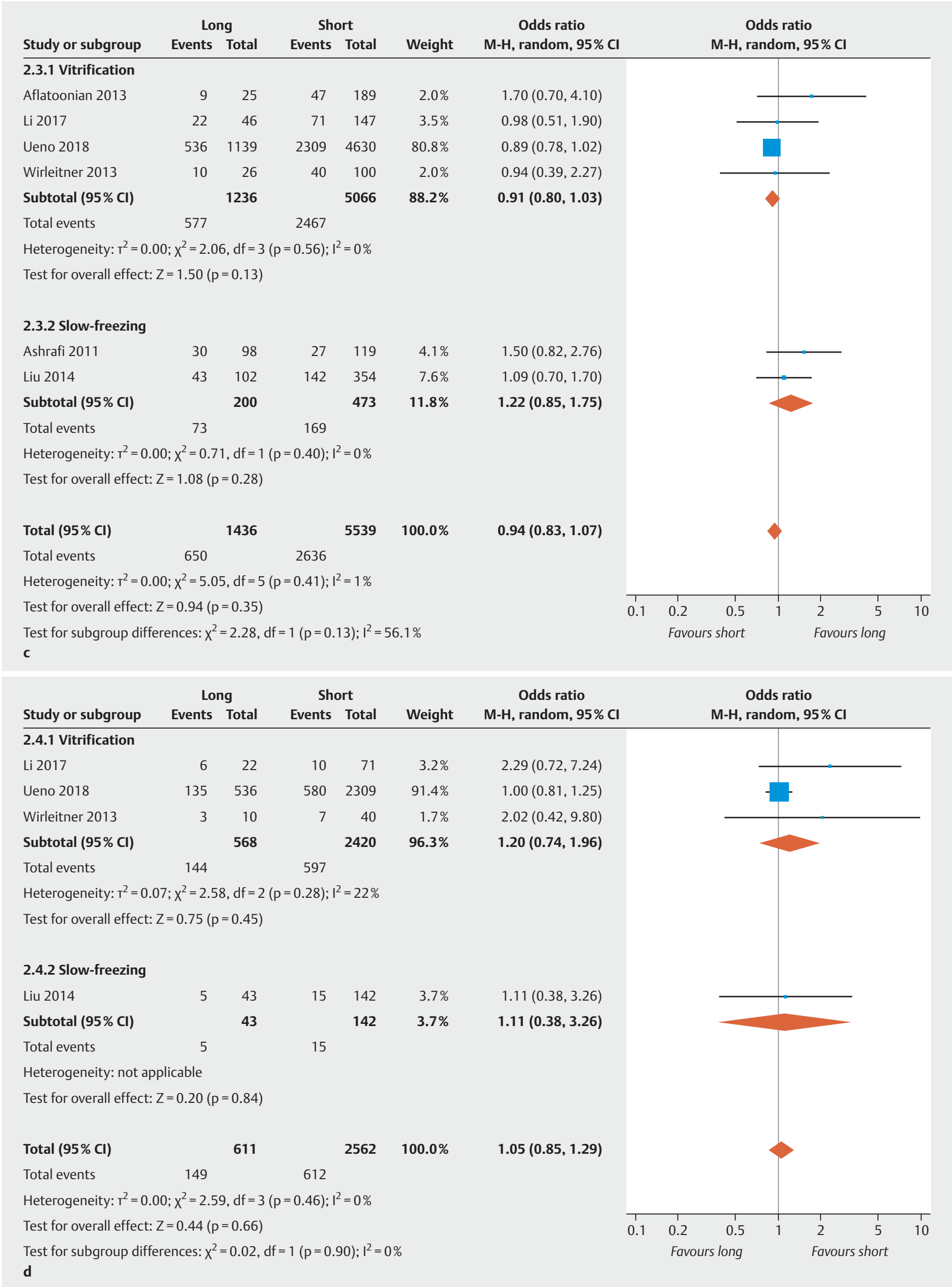




\begin{tabular}{|c|c|c|c|c|c|c|c|c|c|c|c|c|}
\hline \multirow{3}{*}{$\frac{\text { Study or subgroup }}{2.5 .1 \text { Vitrification }}$} & \multicolumn{2}{|c|}{ Long } & \multicolumn{2}{|c|}{ Short } & & \multirow{2}{*}{$\begin{array}{c}\text { Odds ratio } \\
\text { M-H, random, } 95 \% \mathrm{Cl}\end{array}$} & \multirow{2}{*}{\multicolumn{6}{|c|}{$\begin{array}{c}\text { Odds ratio } \\
\mathrm{M}-\mathrm{H} \text {, random, } 95 \% \mathrm{Cl}\end{array}$}} \\
\hline & \multirow[t]{2}{*}{ Events } & \multirow[t]{2}{*}{ Total } & \multirow[t]{2}{*}{ Events } & \multirow[t]{2}{*}{ Total } & & & & & & & & \\
\hline & & & & & Weight & & & & \\
\hline Li 2017 & 16 & 46 & 61 & 147 & $10.2 \%$ & $0.75(0.38,1.50)$ & & & - & & & \\
\hline Ueno 2018 & 401 & 1139 & 1729 & 4630 & $54.1 \%$ & $0.91(0.80,1.04)$ & & & ( & & & \\
\hline Wirleitner 2013 & 7 & 26 & 33 & 100 & $5.7 \%$ & $0.75(0.29,1.96)$ & & & & & & \\
\hline Subtotal $(95 \% \mathrm{Cl})$ & & 1211 & & 4877 & $70.0 \%$ & $0.90(0.79,1.03)$ & & & & & & \\
\hline Total events & 424 & & 1823 & & & & & & & & & \\
\hline \multicolumn{13}{|c|}{ Heterogeneity: $\mathrm{T}^{2}=0.00 ; \mathrm{X}^{2}=0.44, \mathrm{df}=2(\mathrm{p}=0.80) ; \mathrm{I}^{2}=0 \%$} \\
\hline \multicolumn{13}{|c|}{ Test for overall effect: $Z=1.54(p=0.12)$} \\
\hline \multicolumn{13}{|l|}{ 2.5.2 Slow-freezing } \\
\hline Liu 2014 & 38 & 102 & 127 & 354 & $19.4 \%$ & $1.06(0.67,1.68)$ & & & & & & \\
\hline Riggs 2010 & 21 & 86 & 21 & 148 & $10.6 \%$ & $1.95(1.00,3.84)$ & & & & & & \\
\hline Subtotal $(95 \% \mathrm{Cl})$ & & 188 & & 502 & $30.0 \%$ & $1.37(0.76,2.46)$ & & & & & & \\
\hline Total events & 59 & & 148 & & & & & & & & & \\
\hline \multicolumn{13}{|c|}{ Heterogeneity: $\mathrm{T}^{2}=0.10 ; \mathrm{x}^{2}=2.16, d f=1(p=0.14) ; \mathrm{I}^{2}=54 \%$} \\
\hline \multicolumn{13}{|c|}{ Test for overall effect: $Z=1.04(p=0.30)$} \\
\hline Total $(95 \% \mathrm{Cl})$ & & 1399 & & 5379 & $100.0 \%$ & $0.99(0.78,1.25)$ & & & & & & \\
\hline Total events & 483 & & 1971 & & & & & & & & & \\
\hline \multicolumn{13}{|c|}{ Heterogeneity: $\mathrm{T}^{2}=0.02 ; \mathrm{x}^{2}=5.60, \mathrm{df}=4(p=0.23) ; 1^{2}=29 \%$} \\
\hline \multicolumn{7}{|c|}{ Test for overall effect: $Z=0.11(p=0.91)$} & 0.2 & 0.5 & 1 & 2 & 5 & 10 \\
\hline \multicolumn{7}{|c|}{ Test for subgroup differences: $x^{2}=1.82, d f=1(p=0.18) ; 1^{2}=45.0 \%$} & Favo & short & & Favo & ong & \\
\hline
\end{tabular}

e

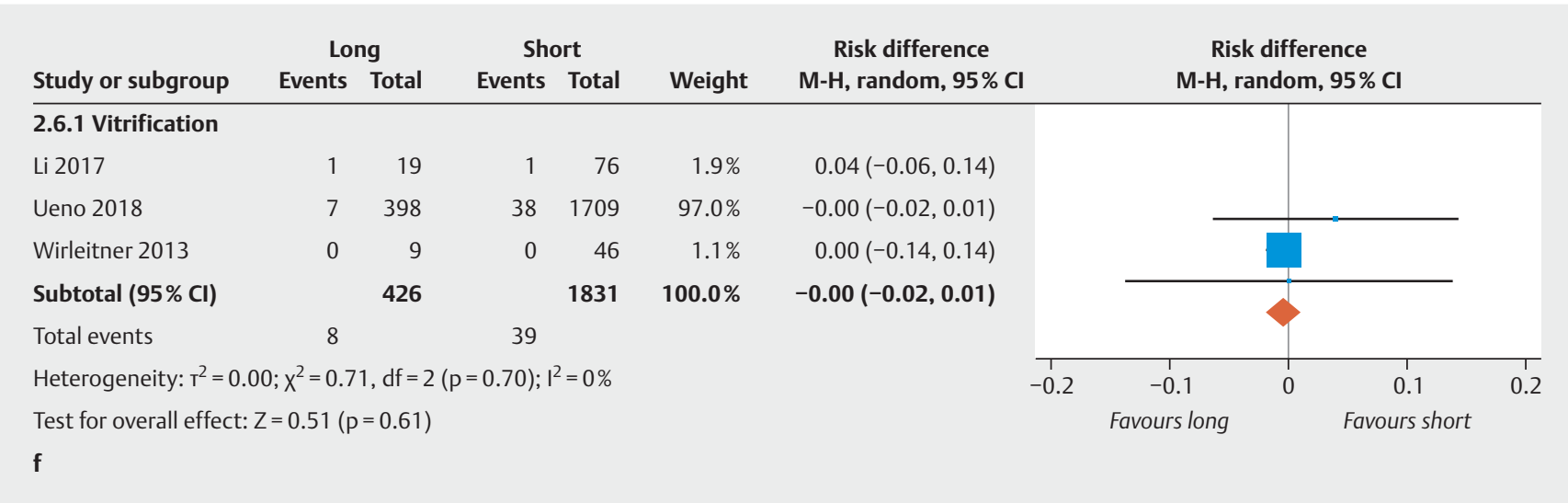

- Fig. 2 Summary of OR or RD of pregnancy outcomes, the highest vs. the lowest storage time category. a Survival rate. b Implantation rate. c Clinical pregnancy rate. $\mathbf{d}$ Miscarriage rate. e Live birth rate. $\mathrm{f}$ Congenital malformation rate.

size of this study is the largest to date, the storage time-frame was one of the shortest compared to the studies we included in our meta-analysis. All embryos were cryopreserved by vitrification, and most embryos (92.8\%) were in the cleavage stage when they were transferred. Surprisingly, the clinical pregnancy rate and live birth rate were significant lower in the group with times of more than 3 months compared with the group with times of less than 3 months. This result challenges the principles of cryobiology and should be treated with caution. We speculate that other fac- tors such as temperature fluctuations due to frequently opening the liquid tank may have had an impact in addition to the 3-month storage time.

There are many potential confounders, such as female age at the time of oocyte retrieval, female BMI, infertility type, infertile years, causes of infertility, parity, embryo quality, stage of embryo development, and number of transferred embryos, which can influence the results. Although there is no question that female age at the time of oocyte retrieval is one of the major confounders 
[25], it is still not known whether female age at the time of embryo transfer matters. However, we could not draw any conclusions since only two studies provided these data [4, 7]. This should be investigated in future studies.

In vitrification, embryos are cooled much more rapidly to prevent the formation of ice crystals and this is therefore presumed to cause less damage to embryos. But the high concentration of cryoprotectants used in vitrification might be cytotoxic and lead to osmotic shock [26]. The main problem with slow-freezing is the formation of intracellular ice, resulting in cell damage and developmental arrest [27]. Compared to vitrification, slow-freezing may cause additional damage to embryos which is not visible on microscopic examination but may adversely affect embryo viability [28]. We found survival rates, implantation rates, clinical pregnancy rates and live birth rates were higher for vitrification than for slow-freezing, which was also in accordance with the results of previous papers $[26,29]$. As this technique significantly increases embryo survival rates compared to slow-freezing, it has led to an improvement in clinical outcomes of cryopreserved cycles and made fertility preservation an available option for patients. Vitrification is now considered to be the best choice to cryopreserve both human oocytes and embryos, due to its high survival rate [30]. It is worth mentioning that the implantation rate (OR $0.84,95 \% \mathrm{Cl}[0.57,1.24])$, clinical pregnancy rate (OR $0.91,95 \% \mathrm{Cl}[0.80,1.03])$ and live birth rate (OR $0.90,95 \% \mathrm{Cl}$ $[0.79,1.03])$ for long storage time groups all showed a decreasing trend for vitrification. Conversely, implantation rates (OR 1.24, $95 \% \mathrm{Cl}[0.90,1.72])$, clinical pregnancy rates (OR $1.22,95 \% \mathrm{Cl}$ $[0.85,1.75])$ and live birth rates (OR 1.37, 95\% Cl $[0.76,2.46])$ in long storage time groups had a tendency to increase following slow-freezing. It is not clear why all three outcomes tended in opposite directions for vitrification and slow-freezing, although the differences between groups did not meet conventional levels of statistical significance. There are several points we need to consider. First, only limited data on patients' characteristics were available. For example, female age at the time of oocyte retrieval and embryo transfer are important confounders. However, few studies reported female age. Another important issue was the reason why patients delayed the timing of FET. A reasonable explanation was that female patients became pregnant in a previous embryo transfer cycle. Therefore, they delayed the timing of the next FET. They might have been expecting a better prognosis when they underwent FET in the next pregnancy. In addition, our analysis only included seven studies. If the number of studies had been higher, the results might be different.

Although storage time did not influence pregnancy outcomes in our study, in clinical practice, manipulations, such as repeated opening of the cryo-tank, transportation of specimens or laboratory procedures over time, may influence pregnancy outcomes. It was thought that annual cleaning and registering might decrease the frozen-thawed survival rate of sperm specimens with longer storage times (5-15 years) [31]. The composition of the preimplantation human embryo culture media and its stability during storage varied [32]. It is possible that the embryos stored for a long time were not the best, as embryologists would thaw the best embryos first. These outcomes should therefore be continuously monitored. Embryo cryopreservation is also a social prob- lem, and issues such as the duration of cryopreservation, the number of cryopreserved embryos, the consent rules for storing embryos, etc., all need legislation [33, 34].

To the best of our knowledge, this is the first meta-analysis investigating the relationship between the duration of embryo cryostorage and pregnancy outcomes. We tried to include all suitable studies without restriction with regard to region, publication type, and language, and investigated the quantitative relation between embryo cryostorage duration and pregnancy outcomes using a dose-response meta-analysis. The current evidence supports the idea that cryopreservation does not affect the differentiation potential of embryos and offers women the opportunity to have their own healthy children in the future. Our meta-analysis had several limitations. Firstly, the meta-analysis was based on a small number of studies and should therefore be treated with caution. Secondly, the OR or RD and $95 \% \mathrm{Cl}$ were estimated using a random-effects model which led to information bias. Thirdly, the maximum storage time we evaluated was 96 months. Moreover, the developmental stage of embryos differed. Lastly but not least, our meta-analysis was conducted using summarized statistics rather than individual data. Acquiring and examining individual data would give a more accurate picture of the dose-response relationship and offer better control of potential residual confounders.

In conclusion, our dose-response meta-analysis showed that long-term storage of human cryopreserved embryos did not impact pregnancy outcomes.

\section{Conflict of Interest}

The authors declare that they have no conflict of interest.

\section{References}

[1] Trounson A, Mohr L. Human pregnancy following cryopreservation, thawing and transfer of an eight-cell embryo. Nature 1983; 305: 707709

[2] Kupka MS, D’Hooghe T, Ferraretti AP et al. Assisted reproductive technology in Europe, 2011: results generated from European registers by ESHRE. Hum Reprod 2016; 31: 233-248

[3] Yan J, Suzuki J, Yu X et al. Effects of duration of cryo-storage of mouse oocytes on cryo-survival, fertilization and embryonic development following vitrification. J Assist Reprod Genet 2011; 28: 643-649

[4] Ueno S, Uchiyama K, Kuroda T et al. Cryostorage duration does not affect pregnancy and neonatal outcomes: a retrospective single-centre cohort study of vitrified-warmed blastocysts. Reprod Biomed Online 2018; 36: 614-619

[5] Li W, Zhao W, Xue X et al. Influence of storage time on vitrified human cleavage-stage embryos froze in open system. Gynecol Endocrinol 2017; 33: 96-99

[6] Liu Q, Lian Y, Huang J et al. The safety of long-term cryopreservation on slow-frozen early cleavage human embryos. J Assist Reprod Genet 2014; 31: 471-475

[7] Wirleitner B, Vanderzwalmen P, Bach $\mathrm{M}$ et al. The time aspect in storing vitrified blastocysts: its impact on survival rate, implantation potential and babies born. Hum Reprod 2013; 28: 2950-2957

[8] Aflatoonian N, Pourmasumi S, Aflatoonian A et al. Duration of storage does not influence pregnancy outcome in cryopreserved human embryos. Iran J Reprod Med 2013; 11: 843-846 
[9] Ashrafi M, Jahangiri N, Hassani F et al. The factors affecting the outcome of frozen-thawed embryo transfer cycle. Taiwan J Obstet Gynecol 2011; 50: 159-164

[10] Riggs R, Mayer J, Dowling-Lacey D et al. Does storage time influence postthaw survival and pregnancy outcome? An analysis of 11,768 cryopreserved human embryos. Fertil Steril 2010; 93: 109-115

[11] Yuan Y, Mai Q, Ma J et al. What was the fate of human embryos following long-term cryopreservation (>/=12 years) and frozen embryo transfer? Hum Reprod 2019; 34: 52-55

[12] Dowling-Lacey D, Mayer JF, Jones E et al. Live birth from a frozen-thawed pronuclear stage embryo almost 20 years after its cryopreservation. Fertil Steril 2011; 95: 1120-1121

[13] Orsini N, Li R, Wolk A et al. Meta-analysis for linear and nonlinear doseresponse relations: examples, an evaluation of approximations, and software. Am J Epidemiol 2012; 175: 66-73

[14] Desquilbet L, Mariotti F. Dose-response analyses using restricted cubic spline functions in public health research. Stat Med 2010; 29: 10371057

[15] Stang A. Critical evaluation of the Newcastle-Ottawa scale for the assessment of the quality of nonrandomized studies in meta-analyses. Eur J Epidemiol 2010; 25: 603-605

[16] Liberati A, Altman DG, Tetzlaff ] et al. The PRISMA statement for reporting systematic reviews and meta-analyses of studies that evaluate health care interventions: explanation and elaboration. PLoS Med 2009; 6: e1000100

[17] Tripepi G, Jager KJ, Stel VS et al. How to deal with continuous and dichotomic outcomes in epidemiological research: linear and logistic regression analyses. Nephron Clin Pract 2011; 118: c399-c406

[18] MANTEL N, HAENSZEL W. Statistical aspects of the analysis of data from retrospective studies of disease. J Natl Cancer Inst 1959; 22: 719-748

[19] Greenland S, Longnecker MP. Methods for trend estimation from summarized dose-response data, with applications to meta-analysis. Am J Epidemiol 1992; 135: 1301-1309

[20] Pruksananonda K, Rungsiwiwut R, Numchaisrika P et al. Eighteen-year cryopreservation does not negatively affect the pluripotency of human embryos: evidence from embryonic stem cell derivation. Biores Open Access 2012; 1: 166-173

[21] Pogozhykh D, Pogozhykh O, Prokopyuk V et al. Influence of temperature fluctuations during cryopreservation on vital parameters, differentiation potential, and transgene expression of placental multipotent stromal cells. Stem Cell Res Ther 2017; 8: 66

[22] Glenister PH, Thornton CE. Cryoconservation-archiving for the future. Mamm Genome 2000; 11: 565-571

[23] Praveen KM, Shyama SK, Kashif S et al. Effects of gamma radiation on the early developmental stages of Zebrafish (Danio rerio). Ecotoxicol Environ Saf 2017; 142: 95-101

[24] Li J, Yin M, Wang B et al. The effect of storage time after vitrification on pregnancy and neonatal outcomes among 24698 patients following the first embryo transfer cycles. Hum Reprod 2020; 35: 1675-1684

[25] Tan TY, Lau SK, Loh SF et al. Female ageing and reproductive outcome in assisted reproduction cycles. Singapore Med J 2014; 55: 305-309

[26] Loutradi KE, Kolibianakis EM, Venetis CA et al. Cryopreservation of human embryos by vitrification or slow freezing: a systematic review and meta-analysis. Fertil Steril 2008; 90: 186-193

[27] Shaw JM, Jones GM. Terminology associated with vitrification and other cryopreservation procedures for oocytes and embryos. Hum Reprod Update 2003; 9: 583-605

[28] Richter KS, Ginsburg DK, Shipley SK et al. Factors associated with birth outcomes from cryopreserved blastocysts: experience from 4,597 autologous transfers of 7,597 cryopreserved blastocysts. Fertil Steril 2016; 106: 354-362

[29] Rienzi L, Gracia C, Maggiulli R et al. Oocyte, embryo and blastocyst cryopreservation in ART: systematic review and meta-analysis comparing slow-freezing versus vitrification to produce evidence for the development of global guidance. Hum Reprod Update 2017; 23: 139-155

[30] Trounson A. Development of in vitro fertilization in Australia. Fertil Steril 2018; 110: 19-24

[31] Huang C, Lei L, Wu HL et al. Long-term cryostorage of semen in a human sperm bank does not affect clinical outcomes. Fertil Steril 2019; 112: 663-669

[32] Tarahomi M, Van Straalen JP, Vaz FM et al. The composition of human preimplantation embryo culture media and their stability during storage and culture. Hum Reprod 2017; 32: i26-i27

[33] Hartshorne G, Sheldon S, Sozou P. On consent rules for storing embryos. Mol Hum Reprod 2009; 24: i49

[34] Bowen-Simpkins P, Wang J, Ahuja KK. The UK's anomalous 10-year limit on oocyte storage: time to change the law. Reprod Biomed Online 2018; 37: 387-389 